2nd International Conference Global Ethics -Key of Sustainability (GEKoS) | May 14, 2021 | Bucharest, Romania

\title{
Teaching Corporate Social Responsibility and Business Ethics at Economic Programs
}

\author{
Iza GIGAURI , Mirela PANAIT, Maria PALAZZO \\ https://doi.org/10.18662/lumproc/gekos2021/3
}

How to cite: Gigauri, I., Panait, M., \& Palazzo, M. (2021). Teaching corporate social responsibility and business ethics at economic programs. In A. Grigorescu \& V. Radu (vol. ed.), Lumen Proceedings: Vol. 15. 2nd International Conference Global Ethics - Key of Sustainability (GEKoS) (pp. 24-37). Iasi, Romania: LUMEN Publishing House. https://doi.org/10.18662/lumproc/gekos2021/3 
Iza GIGAURI et al. | Lumen Proceedings 15 | GEKoS 2021

\title{
Teaching Corporate Social Responsibility and Business Ethics at Economic Programs
}

\author{
Iza GIGAURI ${ }^{1}$, Mirela PANAIT ${ }^{2 *}$, Maria PALAZZO ${ }^{3}$
}

\begin{abstract}
The pandemic is seen as an opportunity to further advance in business ethics. Prof. Freeman called academics to contribute to developing more ethical business models. Businesses have been revising their missions towards more ethical business models as the pandemic has changed attitudes to life. Society expects that companies will serve human beings rather than solely maximization of profit to their stakeholders. This research is motivated by analyzing the importance of teaching business ethics. This research has looked into the directions of business education in terms of corporate social responsibility (CSR) and business ethics. The article intends to highlight the potential of CSR education in overcoming the pandemic crisis and increasing the wellbeing of society. This desk research underlines the standpoint of universities whether they should teach business ethics or CSR at the business faculties, and analyzes the educational programs of the business faculties to find out their attitude towards teaching of CSR/ethics.
\end{abstract}

Keywords: corporate social responsibility, business ethics, education, stakeholders, pandemic crisis.

\footnotetext{
${ }^{1}$ St. Andrews Georgian University, Tbilisi, Georgia, i.gigauri@sangu.edu.ge

2 Petroleum-Gas University of Ploiesti \& Institute of National Economy, Bucharest, Romania, mirela.matei@upg-ploiesti.ro

3 University of Salerno, Salerno, Italy, mpalazzo@,unisa.it
} 
Iza GIGAURI et al.| Lumen Proceedings 15 | GEKoS 2021

\section{Introduction}

The COVID-19 pandemic and economic crisis caused by it forced business and society to transform (Gigauri, 2021). Customer behavior changed and strategies based on the increased spending need to be reconsidered. Society expects ethical behavior from brands and hopes that companies will commit to tackle the new coronavirus and resolve the economic difficulties. Freeman suggested that the current pandemic crisis is an opportunity for business ethics to be changed (Freeman, 2020). Accordingly, the role of business ethics academics has been altering as well, by which they should examine business activities and suggest new approaches. In order to deal with the pandemic crisis, companies need to shift their attention towards human development, human innovation, and growth (Freeman, 2020), (Mushkudiani et al., 2020). In this regard, business school professors play an important role in developing responsible business leaders. Freeman (2020) suggests that academics should teach students that the future depends on their commitment, on their ethical behavior to make business better.

When Andrew Stark paid attention to teaching business ethics in 1993, there were no business schools in Georgia as in almost all post-soviet countries at that time, and consequently no awareness on business ethics. But about three-quarters of America's corporations were building ethics into their organizations (Stark, 1993). Conversely, business ethics and CSR is in the initial stage in Georgia. The abovementioned article devoted attention to teaching ethics in the light of real-world problems, so that managers could apply the concepts in their practice (Stark, 1993). In Georgia, many Ethics courses have still to explain to students that the only responsibility of a company is no more to maximize shareholders' profit as Friedman argued (Friedman, 1970), but CSR is becoming the company's commitment to society's well-being if they want to survive and succeed (Ciutacu et al., 2005), (Matei, 2013), (Voica \& Stancu, 2021). However, it is time to bring CSR to a higher level and teach how to implement the concept. Thus, this paper evaluates the increased role of CSR and business ethics in business education. There is a focus on the fact that developing ethical and responsible leaders can positively impact on the overall wellbeing of society.

Close analysis of CSR projects participating in the competition for Social Responsibility "Meliora" in Georgia (Meliora, 2020), demonstrates the lack of CSR knowledge of the companies and managers. They are not fully aware of what CSR exactly means and how it differentiates from a pure charity. On the other hand, the comprehensive analysis of the educational 
programs of Georgian universities shows that there is either CSR or business ethics included in their program.

Students need to think about any concept from various perspectives. CSR for example will show the other side of business purpose to maximize the profit. In a similar vein, it is essential to teach the importance of strategic planning and preparedness. Companies do not like to invest in scenario planning, as it seems inefficient because it may not happen and why waste time and resources. However, in the vague world, it is impossible to predict the future, and if something happens, systems or procedures need to be in place. Furthermore, it is also important to teach future managers to listen to different opinions especially from people outside their circles, to be well informed. Besides, teaching only through normative theory - what is right and what is wrong cannot enable graduates to act accordingly in the real world. When coping with ethical challenges one needs the courage to speak up and to make ethical choices.

\section{Problem Statement}

The Covid-19 pandemic has clearly demonstrated an unfair wealth distribution not only among countries but also within countries. Globalization created a highly competitive environment for businesses that triggered a demand for innovation (Grigorescu et al., 2020). To respond to this phenomenon, universities are focused on developing professional skills and competencies in business subjects (Hodges et al., 2015). Globalization implies non-ethical dimensions as well as negative effects on the environment (Constantinescu \& Platon, 2014; Neagu, 2020; Surugiu \& Surugiu, 2009), as the scale of production increases. However, corporate social responsibility (CSR) means that economic growth is in line with environmental and social dimensions to ensure sustainable growth (Ene \& Panait, 2017; Matei, 2013; Neagu, 2020; Palazzo, 2019). Additionally, customers living in the information age are educated enough to expect more ethical production processes from a company. They are cautious about companies with the highest profit, depleting natural resources, polluting the environment, or exploit the labor workforce(Grigorescu et al., 2020; Matei, 2013).

Therefore, demands for talents with an ethical train can be grown. Gradually, the demand for CSR specialists has been increasing also in Georgia, as around the world. Since concerns regarding the ecological and environmental impacts of an enterprise are increasing globally, the corresponding legislation takes into account ethical and sustainable issues 
(Ion, 2020). As knowledge, innovation, and entrepreneurship is regarded as an engine for economic development, business educational programs gain more attention. Studying entrepreneurship should awake student's interest to become entrepreneurs, which provokes discussion about suitable teaching methods and education programs (Akhuemonkhan et al., 2013; Gabadeen \& Raimi, 2012; Hysa \& de Mansi, 2020; Panait et al., 2015; Raimi et al., 2013; State, 2020; Wale-Oshinowo et al., 2018). The researchers emphasize the importance of the Socratic approach when dealing with business ethics (Demuijnck, 2020). Therefore, professors should teach how to pose the right questions. The previous researches claim that educators can encourage critical thinking and creativity to approach real problems in the complex world by teaching students to become active learners (Chandler \& Teckchandani, 2015). This can be achieved by rethinking how to teach rather than what to teach, so discussions and dialogue play an essential role (Chandler \& Teckchandani, 2015).

The perception of ethics depends on various factors such as education, family, friends, positive and negative events in a person's life (Sandu, 2020). Consequently, one individual can think about a behavior ethically whereas another individual can consider the same behavior unethical. To solve this issue, companies create professional codes of ethics that standardize good practice (Sandu, 2020). In this respect, teaching CSR that includes cases of moral and immoral behaviors, ethical and unethical actions, has the potential to form the right values, and increase the responsibility of business graduates. It is to be mentioned that in order to solve crises, responsibility and sustainability should be taken into consideration. Consequently, a transformation of business schools is suggested to provide solutions (Dyllick, 2015).

Researchers outline the development of critical thinking (O'Boyle \& Sandonà, 2014) and analytical skills for students to cope with complex reallife problems by discussing cases and understanding the consequences of actions (McCord et al., 2015). They suggest the need to develop a sense of corporate and ethical responsibility (McCord et al., 2015). Therefore, interest in teaching courses in CSR and business ethics is growing. Additionally, leaders taking difficult decisions need to consider ethical dimensions to create value for society (Bistrong, 2020). They should integrate ethical stories in their leadership. Since employees follow leaders' behavior, ethical leaders trigger ethical behavior in an organization, and hence, can make the world better(Bistrong, 2020).

In the current pandemic crisis, ethical leaders should ensure the balance between commercial fast decisions and ethical decision-making, which requires slower, deliberative thinking (Bistrong, 2020; Bazerman, 
2020). The speed leads to unethical decisions. It is predicted that the workforce will change because of the stress and uncertainty caused by the crisis, which makes them anxious (Bazerman, 2020). Moreover, companies are enforced to act quickly and focus on surviving urgent threats (Scoblic, 2020). Thus, the tyranny of the present emerges, and the lack of experience makes it impossible to imagine a possible outcome of a decision (Scoblic, 2020). In order to liberate from the "Tyranny of Present", leaders need to visualize the future and find ways to deal with the current crisis with ethical and purposeful decisions (Bazerman, 2020).

Furthermore, business leaders need to know scenario planning and understand What Ifs. Judgment skills are required as there is no historical analogy of this pandemic crisis to foresee the future (Scoblic, 2020). The case study methods help students to develop judgment and provide them with analogies to prepare them for an ambiguous future (Scoblic, 2020). Consequently, by teaching ethics and responsibility to future business leaders, educators should focus on experiential learning to initiate discussions about different moral problems and help students to figure out how to reason in difficult situations taking into consideration values and integrity. Stakeholder theory has the ability to lessen diffusion of responsibility and can show students who can be affected by managers' decisions from various perspectives. It demonstrates the relationship between business and society (Ostas \& Loeb, 2008). The research indicated that MBA students view "ethical concerns as relatively minor matters as compared to legal or economic concerns" (Ostas \& Loeb, 2008). Therefore, the goal of teaching CSR is to help students understand the powerful role of a manager to accept responsibility in his/her decisions (Ostas \& Loeb, 2008). Thus, the central role of ethics should be accentuated in the CSR classes. Furthermore, teaching ethics with feature films can present values and ethical dilemmas while simulating real-life situations (O'Boyle \& Sandonà, 2014).

Besides, CSR standard ISO 26000 includes important information that needs to be taught at business schools (Moratis, 2014). Maxfield even suggests teaching economics through the lenses of CSR (Maxfield, 2011). However, the research results of Chirieleison (2017) revealed that CSR education is not mainstreamed into core business courses, but CSR courses in Italian universities are increasing. The researcher highlights the importance of students' viewpoints to effectively deliver CSR courses(Chirieleison, 2017). He is of opinion that students' attitude to mandatory CSR courses differs from other courses that embed CSR (Chirieleison, 2017). The research at a Polish university figured out that students consider CSR/ ethics courses as important for business education 
(Tormo-Carbó et al., 2016). But the researchers have concerns regarding effectiveness of such courses because of students' ethical awareness (TormoCarbó et al., 2016). The teaching approach influences student engagement in the CSR course and their satisfaction with the course (Burga et al., 2017). Experiential learning method can increase the consciousness of the millennial generation (Burga et al., 2017). Regarding assessing student learning of CSR, researchers suggest CSR projects, essays, presentations, debates between two groups of students, but also exams and quizzes to evaluate their formal knowledge (Tickell et al., 2017).

\section{Research Questions}

This research will lay the foundation for a large-scale study that will answer the following questions: Do the business education and teaching methods give a knowledge of the social roles, purposes, and responsibilities of the business? Accordingly, the sub-questions emerged:

- What should be taught at the business ethics/ CSR classes?

- How it should be taught - which educational approaches should be employed?

- Who should teach CSR/ business ethics?

- Should the teaching be less theoretical and more practical, and to what extent?

- Should the teaching focus on the theory that explains unethical decisions so students can be aware of the factors influencing decision-making?

- What skills need ethical leaders to cope with an ambiguous future?

\section{Research Methods}

The study consisted of analysis around 125 programs of 55 Higher Education Institutions (HEIs) in Georgia. First, a list of all Georgian higher education institutions with their website addresses was compiled. Then, the analysis of secondary sources from official Websites has been performed. All business programs were examined in order to find whether CSR or Business ethics courses are taught. Then, an investigation was conducted to find if those courses are core or elective and on what degree are they taught, and by whom - an invited lecturer or academic personnel. Therefore, in this way, it could be understood how important business ethics/CSR for a university is. 
Finally, the information from the program managers was collected by Email when there were not enough details on their websites. The research took place between February and March 2021.

\section{Findings}

According to National Center for Educational Quality Enhancement (n.d.), there are three types of higher education institutions in Georgia: University, Teaching university, and College. At the moment, there are 31 universities, 20 teaching universities, and 4 colleges. In total, 55 HEIs are accredited. All websites of HEIs in Georgia were studied. The web addresses are available on the webpage of the National Center for Educational Quality Enhancement.

Table 1. The research results. Source: HEIs Websites

\begin{tabular}{|l|l|}
\hline HEIs in Georgia & 55 \\
\hline $\begin{array}{l}\text { Faculty Business/ Economics/ } \\
\text { Program in Business Administration }\end{array}$ & 40 \\
\hline CSR course & 10 (including 8 universities) \\
\hline Business Ethics course & 13 (including 8 universities) \\
\hline CSR and Business ethics & 6 programs \\
\hline BA degree & 20 \\
\hline MA/ MBA degree & 6 \\
\hline PhD degree & 0 \\
\hline Core & 10 (including 6 universities) \\
\hline Elective & 12 (including 10 universities) \\
\hline Academic Personnel & 6 \\
\hline Invited Lecturer & 5 \\
\hline
\end{tabular}

The desk research has been conducted in order to analyze how many HEIs in Georgia have CSR / Business Ethics in their programs. Most universities have their educational programs and curricula available on their websites. $40 \mathrm{HEIs}$ out of 55 have business faculty/school; among them are 24 out of 31 universities (Table 1). However, only ten HEIs including eight universities mentioned CSR in their programs, and thirteen HEIs (eight universities) offer ethics/ business ethics classes. It should be mentioned that six programs include subject titles "CSR and Business ethics". Twenty 
business faculties offer CSR or business ethics courses in the Bachelor's degree, and five universities and one teaching university - in the Master's degree. It should be noted that 3 business schools offer those courses at both degrees: BA and MA /MBA. None of Doctoral programs include CSR/ Business ethics classes. At twelve HEIs (including ten universities), $\mathrm{CSR} /$ business ethics is an elective course, and ten of them (including six universities) make those courses compulsory. At five universities and one other HEI, the course is taught by invited lecturers, whereas at six HEIs, the lectures in CSR/ Business ethics are delivered by academic personnel.

\section{Discussions}

Higher Educational Institutions are vital the world economy as they promote sustainable development principles and further development of CSR and business ethics (Hysa E., \& Ur Rehman, 2019; Hoxhaj \& Hysa, 2015; Panait et al., 2015; Raimi et al., 2013; Vasile et al., 2007). Universities have the potential to study the phenomenon, teach it, promote it, and create awareness about it. Therefore, all three functions of universities - teaching, research, and entrepreneurship must be under the sign of CSR and business ethics. Given the large number of specific stakeholders, their impact on promoting CSR and business ethics is substantial as they may be some of the most important promoters of these concepts alongside transnational corporations.

Given the importance of education on training professionals in the fields of corporate social responsibility and business ethics, universities are essential components of the Global Compact platform launched by the United Nations. Moreover, higher education institutions have made constructive criticisms regarding the operations carried out by the Global Compact, have contributed to the elaboration and implementation of specific principles, namely The Principles for Responsible Management Education - PRME (2007). The implementation of these principles will contribute to the improvement and updating of education and research plans, teaching methodologies, and institutional strategies.

Ethics and CSR lectures should focus on developing innovative and imaginative thinking, judgment, and skills for practical use of the theoretical notions. Students need to know how to identify solutions for ethical issues in the vague future, and how to cope with uncertainties in the real working environment after they graduate. In addition, students should acquire communication skills specific to CSR actions given the large number and diversity of company-specific stakeholders, understand the importance of 
standards for reporting the social and environmental performance of economic agents and be aware of the pitfalls involved by green washing or window dressing strategies. Generally, research of CSR and business ethics is far ahead of both teaching and practical use of the concepts. The research activity must have a strong applicative character so that (1) to find solutions to maximize the non-financial performance of companies, (2) to propose measures by which public authorities or institutions with the role of supervision, regulation, control, or protection consumers to encourage the responsible and ethical behavior of economic agents, (3) to identify ways to standardize non-financial reporting so that stakeholders can more easily make comparisons between companies in different sectors of activity.

\section{Conclusions, limitations and future research}

Universities have become important players in the race for sustainable development, acting simultaneously on several levels (1) by training specialists in areas such as CSR, (2) by initiating and running their own CSR programs that focus on environmental protection, supporting disadvantaged local communities or disadvantaged people, (3) as socially responsible investors on the financial market, (4) conducting studies on CSR programs carried out by various entities such as financial institutions, transnational corporations or SMEs.

This research aimed at exploring the importance of teaching business ethics. In reaching its aim, the research demonstrates some limitations and provides several insights for further studies. The investigated data were gathered from the Websites of the HEIs at a single point in time, implying the importance of developing longitudinal studies that can reinforce the exploration and can deeper investigate the selected items in different time periods.

The development level of a country decisively influences the paradigm shift regarding the motivation of student period must benefit from specific CSR courses and business ethics. firms slowly moving from profit maximization for their stockholders to increasing the satisfaction of all categories of stakeholders. The paradigm shift means improving the mentalities of future managers, who during the

Furthermore, the paper focused on a specific country, and future research can discover various regions allowing comparison of gathered data with the results of our study to fully comprehend the importance of teaching business ethics worldwide and to reach a higher degree of generalization. 
Moreover, the culture in diverse countries can impact the selected subjects. This variable could be explored by future research to employ crosscultural data for reinforcing generalizability.

Taking into account the significance of the topic and the time limitations, data were attained by analyzing websites and their sections. Thus, further research has to employ other techniques and methods for exploring the field: this will allow triangulating the data. For example, subsequent research can reveal what business school deans think about CSR education, and how CSR/business ethics professors and lecturers teach the subject. On the basis of the research results, recommendations will be made and the future direction of CSR teaching will be outlined.

Finally, data collection from developing and underdeveloped states where education might have different approaches to CSR can enable to obtain more insights on the importance of teaching business ethics, and comprehensive understanding can be gained through the data comparison.

\section{References}

Akhuemonkhan, I. A., Raimi, L., \& Sofoluwe, A. O. (2013). Entrepreneurship education and employment stimulation in Nigeria. Journal of studies in social sciences, 3(1), 55-79. http://infinitypress.info/index.php/jsss/article/view/ 66

Bazerman, M. H. (2020). A New Model for Ethical Leadership. Harvard Business Review. https://hbr.org/2020/09/a-new-model-for-ethical-leadership

Bistrong, R. (2020, August 20). Why the business world is about to need compliance officers more than ever. The FCPA Blog. https://fcpablog.com/2020/08/26/whythe-business-world-is-about-to-need-compliance-officers-more-than-ever/

Burga, R., Leblanc, J., \& Rezania, D. (2017). Analysing the effects of teaching approach on engagement, satisfaction and future time perspective among students in a course on CSR. The International Journal of Management Education, 15(2), 306-317. https://doi.org/10.1016/j.ijme.2017.02.003

Chandler, J. D., \& Teckchandani, A. (2015). Using social constructivist pedagogy to implement liberal learning in business education. Decision Sciences. Journal of Innovative Education, 13(3), 327-348. https://doi.org/10.1111/dsji.12073

Chirieleison, C. (2017). CSR Education in Italian Economics Departments: An Exploratory Study. The Journal of Corporate Citizenship, 65, 12-29. http://dx.doi.org/10.9774/GLEAF.4700.2017.ma.00004

Ciutacu, C., Chivu, L., \& Preda, D. (2005). Company’S Social Responsibility-A 
Iza GIGAURI et al.| Lumen Proceedings 15 | GEKoS 2021

Challenge For Contemporary World. Romanian Journal of Economics, $20(1$ (29)), 79-94. http://www.revecon.ro/articles/2005-1/2005-1-5.pdf

Constantinescu, A., \& Platon, V. (2014). Sustainable development paradigmsynopsis. Annals of Faculty of Economics, 1(1), 116-124.

http://anale.steconomiceuoradea.ro/volume/2014/n1/012.pdf

Demuijnck, G. (2020). What are Ethicists Doing in Corporations?. In A. Grigorescu \& V. Radu (vol. ed.), Lumen Proceedings: Vol. 11. 1st International Conference Global Ethics -Key of Sustainability (GEKoS) (pp. 4-13). Iasi, Romania: LUMEN Publishing House.

https://doi.org/10.18662/lumproc/gekos2020/02

Dyllick, T. (2015). Responsible management education for a sustainable world. Journal of Management Development, 34(1), 16-33. https://doi.org/10.1108/jmd-02-2013-0022

Ene, C., \& Panait, M. (2017). The financial education-Part of corporate social responsibility for employees and customers. Revista Romana de Economie, 44(1), 145-154. https://www.revecon.ro/articles/2017-1/2017-112.pdf

Freeman, R. E. (2020). Business Ethics in the Time of Covid-19. In A. Grigorescu \& V. Radu (vol. ed.), Lumen Proceedings: Vol. 11. 1st International Conference Global Ethics -Key of Sustainability (GEKoS) (pp. 1-3). Iasi, Romania: LUMEN Publishing House. https://doi.org/10.18662/lumproc/gekos2020/01

Friedman, M. (1970, September 13). The Social Responsibility of Business Is to Increase Its Profits. The New York Times Magazine. https://www.nytimes.com/1970/09/13/archives/a-friedman-doctrinethe-social-responsibility-of-business-is-to.html

Gabadeen, W. O., \& Raimi, L. (2012). Management of entrepreneurship education in Nigerian higher institutions: Issues, challenges and way forward. Abuja International Journal of Education and Management Sciences, 2(1), 1-16. https://www.researchgate.net/profile/LukmanRaimi/publication/291043294_Management of Entrepreneurship_Educat ion in Nigerian Higher Institutions Issues Challenges and Way Forwa rd/links/569e93ae08ae21a56424c94b/Management-of-EntrepreneurshipEducation-in-Nigerian-Higher-Institutions-Issues-Challenges-and-WayForward.pdf

Gigauri, I. (2021). New economic concepts shaping business models in postpandemic era. International Journal of Innovative Technologies in Economy, 1(33), 1-11. https://doi.org/10.31435/rsglobal ijite/30032021/7393 
Iza GIGAURI et al. | Lumen Proceedings 15 | GEKoS 2021

Grigorescu, A., Lincaru, C., \& Pîrciog, S. (2020). Ethic Leadership Trigger for Talents. In A. Grigorescu \& V. Radu (vol. ed.), Lumen Proceedings: Vol. 11. 1st International Conference Global Ethics -Key of Sustainability (GEKoS) (pp. 3244). Iasi, Romania: LUMEN Publishing House. https://doi.org/10.18662/lumproc/gekos2020/05

Hodges, N., Watchravesringkan, K., Yurchisin, J., Hegland, J., Karpova, E., Marcketti, S., \& Yan, R.-N. T. (2015). Assessing Curriculum Designed to Foster Students' Entrepreneurial Knowledge and Small Business Skills from a Global Perspective. Family and Consumer Sciences Research Journal, 43(4), 313-327. https://doi.org/10.1111/fcsr.12115

Hoxhaj, J., \& Hysa, E. (2015). Comparing ENQA, British, German \& Albanian Standards of Quality in Higher Education. European Journal of Sustainable Development, 4(2), 243-258. http://dx.doi.org/10.14207/ejsd.2015.v4n2p243

Hysa E., \& Ur Rehman N. (2019). Assessing the Teaching Quality of Economics Programme: Instructor Course Evaluations. Integratsiya obrazovaniya [Integration of Education], 23(4), 556-567. https://doi.org/10.15507/1991-9468.097.023.201904.556-567

Hysa, E., \& Mansi, E. (2020). Integrating teaching and learning in graduate studies: economic development course. Technology transfer: innovative solutions in Social Sciences and Humanities, 3, 61-64. https://doi.org/10.21303/2613$\underline{5647.2020 .001305}$

Ion, A. E. (2020). Ethics and Sustainability in Small and Medium-Sized Enterprises Public Policies. In A. Grigorescu \& V. Radu (vol. ed.), Lumen Proceedings: Vol. 11. 1st International Conference Global Ethics-Key of Sustainability (GEKoS) (pp. 74-85). Iasi, Romania: LUMEN Publishing House. https://doi.org/10.18662/lumproc/gekos2020/09

Matei, M. (2013). Responsabilitatea socială a corporațiilor şi instituţiilor şi dezvoltarea durabilă a României [Social responsibility of corporations and institutions and sustainable development of Romania]. Expert Publishing House.

Maxfield, S. (2011). Teaching Economics to Business Students through the Lens of Corporate Social Responsibility and Sustainability. The Journal of Economic Education, 42(1), 60-69. http://dx.doi.org/10.1080/00220485.2011.536490

McCord, M., Houseworth, M., \& Michaelsen, L. K. (2015). The Integrative Business Experience: Real Choices and Real Consequences Create Real Thinking. Decision Sciences Journal of Innovative Education, 13(3), 411-429. https://doi.org/10.1111/dsji.12070

Meliora. (2020). Meliora: Georgia's Responsible Business Awards. https://meliora.ge/en 
Moratis, L. (2014). ISO 26000: Three CSR Messages for Management Education. The Journal of Corporate Citizenship, 53, 77-90. https://doi.org/10.9774/gleaf.4700.2014.ma.00007

Mushkudiani, Z., Gechbaia, B., Gigauri, I., \& Gulua, E. (2020). Global, economic and technological trends in human resource management development. Access Journal, 1(1), 53-60. https://doi.org/10.46656/access.2020.1.1(4)

National Center for Educational Quality Enhancement (n.d.). Retrieved from: https://eqe.ge/en/page/static/89/umaghlesi-saganmanatleblodatsesebulebebi

Neagu, O. (2020). Does Globalisation Promote Sustainable Development and an Equal Distribution of Income around the World? An Econometric and Ethical View. In A. Grigorescu \& V. Radu (vol. ed.), Lumen Proceedings: Vol. 11. 1st International Conference Global Ethics -Key of Sustainability (GEKoS) (pp. 56-64). Iasi, Romania: LUMEN Publishing House. https://doi.org/10.18662/lumproc/gekos2020/07

O’Boyle, E. J., \& Sandonà, L. (2014). Teaching Business Ethics Through Popular Feature Films: An Experiential Approach. Journal of Business Ethics, 121(3), 329-340. https://doi.org/10.1007/s10551-013-1724-0

Ostas, D. T., \& Loeb, S. E. (2008). Teaching Corporate Social Responsibility In Business Law And Business Ethics Classrooms. Journal of Legal Studies Education, 20(1), 61-88. https://doi.org/10.1111/j.17441722.2002.tb00094.x

Palazzo, M. (Ed.). (2019). Linking Cultural Dimensions and CSR Communication: Emerging Research and Opportunities. IGI Global.

Panait, M., Petrescu, M., \& Podasca, R. (2015). Remodeling the role of universities in the context of sustainable development. Economic Dynamics and Sustainable Development - Resources, Factors, Structures and Policies Proceedings ESPERA 2015 - Part 1, p. 375-383. http://dx.doi.org/10.3726/978-3-653-06571-8

Raimi, L., Shokunbi, M. O., Suara, I. B., \& Fadipe, A. O. (2013). Embedding Islamic Financial System (IFS) in the curricula of schools in Nigeria. Journal of Business Administration and Education, 2(2), 65-84.

http://infinitypress.info/index.php/ibae/article/view/65

Sandu, D. (2020). Ethics and Responsibility in the Collection System of Local Taxes and Fees. In A. Grigorescu \& V. Radu (vol. ed.), Lumen Proceedings: Vol. 11. 1st International Conference Global Ethics -Key of Sustainability (GEKoS) (pp. 129140). Iasi, Romania: LUMEN Publishing House. 
Iza GIGAURI et al. | Lumen Proceedings 15 | GEKoS 2021

\section{https://doi.org/10.18662/lumproc/gekos2020/14}

Scoblic, J. P. (2020 July-August). Learning from the Future: How to make robust strategy in times of deep uncertainty. Harvard Business Review.

https://hbr.org/2020/07/learning-from-the-future

Stark, A. (1993 May-June). What's the Matter with Business Ethics? Harvard Business

Review. https://hbr.org/1993/05/whats-the-matter-with-business-ethics

State, M. (2020). The Efficiency of Entrepreneurial Education Programs in

Romania. In A. Grigorescu \& V. Radu (vol. ed.), Lumen Proceedings: Vol. 11.

1st International Conference Global Ethics -Key of Sustainability (GEKoS) (pp. 65-

73). Iasi, Romania: LUMEN Publishing House.

https://doi.org/10.18662/lumproc/gekos2020/08

Surugiu, C., \& Surugiu, M. R. (2009). Climate change and global economic status.

Present and perspectives. Revista Tinerilor Economisti [The Young

Economists Journal], 1(13S), 121-133. http://feaa.ucv.ro/RTE/013S-

16.pdf

Tickell, G., Paz, V., \& Rahman, M. (2017). Teaching Corporate Social

Responsibility In An MBA Program. Journal of Sustainability Management (JSM), 5(1), 1-10. https://doi.org/10.19030/jsm.v5i1.10153

Tormo-Carbó, G., Oltra, V., Seguí-Mas, E., \& Klimkiewicz, K. (2016). How Effective are Business Ethics/CSR Courses in Higher Education? Procedia Social and Behavioral Sciences, 228, 567-574.

https://doi.org/10.1016/j.sbspro.2016.07.087

Vasile, V., Zaman, G., Pert, S., \& Zarojanu, F. (2007). Restructuring Romania's education system considering the evolutions from the domestic market perspective and impact on RDI progress. European Institute of Romania - Strategy and Policy Studies (SPOS), 2. http://ier.gov.ro/wpcontent/uploads/publicatii/Spos2007 studiu 2 en.pdf

Voica, M. C., \& Stancu, A. (2021). Corporate Social Responsibility Reporting: Background, Evolution and Sustainability Promoter. In C. F. Machado \& J. P. Davim (Eds.), Sustainable Management for Managers and Engineers, (pp. 109155). Wiley-ISTE. https://doi.org/10.1002/9781119804345.ch6

Wale-Oshinowo, B., Raimi, L., Olarewaju, A., \& Mbah, S. (2018). Entrepreneurship Education And Student Entrepreneurial Mindset: A Study Of Students in Federal Government Tertiary Institutions in Lagos, Nigeria. Unilag Journal of Humanities, 6(1), 194-214. http://ujh.unilag.edu.ng/article/view/322/272 